\title{
Reflections and Refractions of Societal Images: The Cultural Formation of Self-Identity in a Middle School Art Classroom
}

\section{Monica Kirchweger}

I am planning to conduct an ethnographic study on how middle school students use images in the context of making art in a classroom setting which utilizes computers as an integral part of the art curriculum. The fieldwork will be carried out over the course of one academic year. Since art is a required subject at the middle school level (as opposed to being an elective at the high school level), the students in this study will reflect a more diverse student population than at the high school level where students self-select their enrollment in art classes.

While the number of qualitative studies done in educational contexts has been steadily on the increase in recent years, middle school classrooms tend to be studied less often than their elementary and high school counterparts. Furthermore, the number of art classrooms in which qualitative research has been conducted makes up only a relatively small portion of this research, and this has often been limited to case studies, educational criticism, and other forms of research which are extremely limited in either the number of participants or in the duration of time over which the fieldwork is conducted. Finally, despite the increasingly wide spread use of computers in the art classroom, very little qualitative research, let alone full scale ethnographies, has been done on the use of this new technology by students and teachers.

So far I have not found a single qualitative study of computer usage in a middle school context. Existing research in this area has occurred only at the elementary, high school, and university levels. Kerry Freedman and Anju Relan $(1989,1990,1992)$ are virtually the only people who have published empirical research on students' use of computers in art education environments to date. In the metropolitan area in which I will be conducting the fieldwork for my dissertation, however, there are at least four middle schools which do use computers in their art classrooms. In fact, computer usage in middle school art classrooms in this locale is greater than at either the elementary or high school levels.

Students at the middle school level are usually just beginning to try to seriously define themselves in terms of who they will become as teenagers and adults. How students at this age relate to the images around them may suggest ways in which they are defining themselves. In our consumer-driven culture we are literally bombarded daily with images. From billboards and magazines to television and movies, the media are projecting images of 
gender, class, race, and so forth in ways that suggest that if one has "the look" of the models in these images, or if one owns the products featured therein, one will be happy, popular, wealthy, and loved. How do these images get understood and/or used by middle school students in the context of making art and in the context of defining their self-identity? Do they value and attempt to emulate them or do they reject the societal images of beauty, glamour, wealth, and success that most of these images project? How does this reflection and/or rejection contribute to the cultural formation of self-identity?

I am interested in a number of avenues of exploration within the context of this study

* What role does gender play in how technology is perceived and used in the art classroom?

* Do images made by students who differ by economic class, gender, race, ethnicity, and so forth create images in unique ways, and is there a visual difference in the content and style of these images?

* Have students evolved distinct and differing thought processes about how best to utilize the computer in the creation of their own images?

* What sort of aesthetics do students attribute toward art made with the use of computers? How does this aesthetic relate to their watching of television shows, MTV, and the movies? Is the computer valued for its ability to produce high-tech special effects or is it valued as a serious art making tool?

* How do students relate to the added dimensionality of time in making works on the computer which are animated and possibly interactive and/or rendered in three dimensions?

* What is the relationship between "official" teacher talk about art and the art that these students are making and valuing in their own cultural spheres.

* With the use of inputting "found" images through the use of digitizing or scanning, what images do students incorporate from popular culture, the mass media, fine art, or family snapshots. Why and how did they use them? How do students define their self-identity in terms of gender, class, race, and so forth in terms of these images? Is written text incorporated into their art work in relation to these images?

Marilyn Zurmuehlen's Working Papers in Art Education 1992 
As the research evolves I know I may find that some of these questions will remain unanswered and unanswerable. Questions other than these may emerge that I cannot possibly conceive of at this early date.

While I am particularly interested in how girls form their sense of selfidentity, I feel that one cannot simply focus solely on one gender and ignore the other. The girls are not in a social vacuum. In addition to being influenced by images and same sex peers, in some form and degree their male classmates, family members, teachers and others within and outside of the school will have positive and/or negative effects on the girl's' conceptions of self. For instance, in Paul Willis' (1977) classic study of working class male youths' transition from secondary schooling to the waged workplace, he focusses almost exclusively on "the lads" a small group of male youths whom he identifies as resisting school culture and valuing the adult culture of the shop floor. One is left wondering about the girls, "ear'oles" (conformist male students), and most of the teachers and parents of "the lads." They are an absent presence in the lads' lives, only being discussed as objects of the lads' activities. Similarly, Christine Griffin (1985) and Linda Valli (1986) have done ethnographic studies of female youths' transition from high school to the job market and have focussed primarily on females, apart from their male counterparts.

While the category of sex is a biological given, gender is a social construct reinforced through cultural discourse which is used to connote the behavior, attitudes, aptitudes, and appearance of human beings. Linda Christian-Smith (1988) has studied teenage girls' engagement with adolescent romance novels and the construction of femininity contained within these gendered discourses. She found that

While teen romances run counter to the realities of many women's and girls' actual lives, they nevertheless serve to maintain traditional views of what should constitute those lives. According to the novels, femininity consists of administering to the heart and tending the hearth. ... Although most of the girls wished for a domestic femininity in the final analysis, the constitution of their femininity was fraught with tremendous conflict. Given the power of cultural products like romance novels in preparing girls for their entrance into heterosexual romance, it is necessary to engage girls in a recognition of the contradictions surrounding femininity, both in narrative texts and in their own lives. (p. 97)

Lois Weis (1990) also has studied high school students in relation to their eventual school leaving and transition to adulthood. Unlike the aforementioned, in this case the students faced bleak employment options upon leaving school. Weis has done a more relational study in that she looked at how the students in this working class area define themselves in relation to their peers across gender and race, as well as to their teachers and

Marilyn Zurmuehlen's Working Papers in Art Education 1992 
parents. What is missing from her analysis of the students' definition of selfidentity is how they relate to the gendered, racial, and class-based discourses of popular culture and the mass media. This absence is particularly apparent when she discusses the girls' contradictory notions of career and family. She wonders why this generation of female youth is so different from their parents aspirations and notions of feminine roles in life, but fails to examine cultural influences outside of their home and school role models. What were the girls reading, watching on television, and viewing at the movies?

I am interested in combining both long-term observation of the middle school art students' interactions with their peers and teachers in relation to art making processes and the "official" art learning that is supposed to be occurring with a semiotic readings of the images these students produce, their discourse about them in class and in interviews, and videotaped footage of their process of working on the computer. I do not subscribe to the positivistic myth of the 'objective' observer or in 'going native' as the naturalistic 'fly-on-the-wall' researcher (Roman, 1987; Roman \& Apple, 1989). Participants will know who I am and why I am there, and my tentative conclusions about the research will be read and reread by the students and teacher as the study evolves. Their responses will be incorporated into the final text. I will also be striving to make the final text accessible to a wider audience by using language in a way that minimizes jargon and is descriptively vivid in the portrayal of the research findings.

\section{References}

Christian-Smith, L.K. (1988). Romancing the girl: Adolescent romance novels and the construction of femininity. In L.G. Roman \& L.K. ChristianSmith (Eds.), Becoming feminine: The politics of popular culture ( $\mathrm{pp}$. 76-101). London: Falmer.

Freedman, K. (1989). Microcomputers and the dynamics of image making and social life in three art classrooms. Journal of Research on Computing in Education, 21, 290-298.

Freedman, K. (1991). Possibilities of interactive computer graphics for art instruction: A summary of research. Art Education, 44 (3), 41-47.

Freedman, K. \& Relan, A. (1990). The use of applications software in school: Paint system image development processes as a model for situated learning. Journal of Research on Computing in Education, 23, 101112.

Griffin, C. (1985). Typical girls? Young women from school to the job market. London: Routledge \& Kegan Paul.

Marilyn Zurmuehlen's Working Papers in Art Education 1992 
Roman, L.G. (1987). Punk femininity: The formation of young women's gender identities and class relations within the extramural curriculum of a contemporary subculture. Unpublished Ph.D. thesis, University of Wisconsin-Madison.

Roman, L.G. \& Apple, M.W. (1989). Is naturalism a move away from positivism? Materialist and feminist approaches to subjectivity in ethnographic research. In E. Eisner \& A. Peshkin (Eds.), Qualitative Inquiry in Education. New York: Teachers' College Press.

Valli, L. (1986). Becoming clerical workers. Boston: Routledge \& Kegan Paul.

Weis, $L$. (1990). Working class without work: High school students in a deindustrializing economy. New York: Routledge.

Willis, P. (1977). Learning to labor: How working class kids get working class jobs. Westmead: Saxon House. 